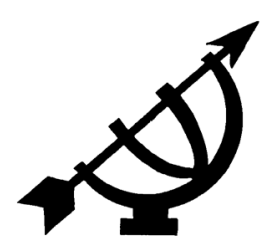

\title{
The formation of Christian leaders: a Wesleyan approach
}

\author{
W. Bentley 1 \\ Department of Philosophy \& Systematic Theology \\ University of South Africa \\ PRETORIA \\ and \\ Glen Methodist \\ Methodist Church of Southern Africa \\ E-mail: wbentley@telkomsa.net
}

\begin{abstract}
The formation of Christian leaders: a Wesleyan approach

The problem of leadership is that it is defined according to a very narrow understanding. It postulates that all people can be divided into two categories. People are either leaders or followers. This article explores the formation of Christian leaders using the model offered by the Wesleyan revival of eigteenthcentury England. It asks what leaders would look like when we use the Wesleyan definition instead of the leader-follower understanding to which we have grown accustomed.
\end{abstract}

\section{Opsomming}

\section{Die vorming van Christenleiers: 'n Wesleyaanse toepassing}

Die probleem met leierskap is dat dit in terme van 'n baie eng definisie verstaan word. Dit stel voor dat alle mense in een van twee kategorieë val. Mense is óf leiers óf volgelinge. Hierdie artikel fokus op die vorming van Christenleiers volgens die model van die agtiende-eeuse Wesleyaanse hernuwing wat in Engeland plaasgevind het. Die vraag word gevra hoe ons leiers sou lyk indien ons, in plaas van die leier-volgelingverstandhouding waaraan ons gewoond geraak het, eerder die Wesleyaanse definisie sou volg.

1 Dr Wessel Bentley is a part-time lecturer in the Department of Philosophy and Systematic Theology at the University of South Africa. 


\section{Introduction}

The notion of Christian leadership is understood in many different ways. The most simplistic interpretation of Christian leadership points to the holding of an office or fulfilling a specific function in a church or Christian community, which demands of the individual to make decisions on other people's behalf. This definition of Christian leadership is characterised by the use of titles and it differentiates between various levels of church participation. In this article I explore the mentioned understanding of Christian leadership and how it has been adopted within the framework of the Christian community. I further explore the model of Christian leadership as found in the Wesleyan tradition, suggesting that this is not only different to what has been suggested by more traditional definitions, but that it offers a way to form people who are able to make a positive difference in their own lives and also in the lives of the broader community.

\section{What is a leader?}

It is very common in civil conversation to differentiate between two types of people. There are leaders and then there are followers. Despite the fact that the sharp distinction between leader and followers has been overcome in leadership theory since the groundbreaking work done by Peter F. Drucker, Douglas McGregor (2000), Robert Greenleaf (1977) and James M. Burns (1982), some people still maintain the old leadership paradigm whereby these two categories are seen in polarised terms. In differentiating between leaders and followers, one may as well be describing the different social orders in an ant colony. Followers are perceived to be people whose gifts do not include the ability to direct or instruct other people, but whose function it is to serve and follow others, in other words, the leaders. These are the "worker-ants".

Leaders, on the other hand, are those who do not make themselves available for the hard, physical labour that is required by the followers. The followers' labour is in a manner of speaking directed towards the maintenance and continuation of society. The leaders direct this work, seeing themselves as the decision-makers, who have the necessary wisdom, knowledge and insight. It is through their oversight that the "worker-ants" commit themselves to work for the benefit of the community as a whole. It is interesting that even in ant-colonies, there is a force between the leaders and the workers, the soldier-ants, who see to it that no worker dare rebel against the leadership. We will not explore this third dynamic in this article. This 
is a very simple illustration, but one which clearly shows the workings within what has been adopted as a dominant model of leadership and followership.

The difference between the leadership found in ant colonies and those found in more democratic environments is that ants cannot choose their leaders. Leaders are given this status from birth. Leadership in democratic societies offer people the opportunity to choose their own leaders, which creates an expectation of what such a leader should offer to those who put them in power. Kretzschmar (2002:46) describes leaders as

... people who have willing followers ... have an impact on the lives and views of people, and on situations and structures ... people who are able to inspire, encourage and guide others.

This definition is correct as it aptly describes the way in which democratic leadership has been received and implemented. But even in this definition we find a hierarchical structure which has proven during the centuries to be pliable and subject to abuse by those who have tasted the nectar of power. Those who have been identified in the community to have the characteristics described in Kretzschmar's definition, and have been put in power, do not always adhere to the expectations of their constituency. In fact, Kretzschmar (2002:48) describes such leaders as having the ability, and perhaps the aim of manipulating people into becoming clones of the leader, abusing their privilege of leadership to form and create in their followers that which would satisfy their own desires. Such leadership does not tolerate followers who are critical, but enforces their obedience (Kretzschmar, 2002:48). This renders the community blind and slavish, and with its spirit broken, becomes a society that is uncreative. Sekou (2007:98-103) further argues that the Christian church has shown in its history an obsession with power, whereby evangelism has gone hand in hand with the domination of those who received the gospel. The so-called Christian leadership shown during colonisation has not done any favours to the Christian faith's image of what leadership should be.

This caution by Kretzschmar is not only to be found in the church's past, but also manifests in the domain of church life in modern experiences. I am sure that the reader can cite their own examples of how seemingly righteous and dignified Christians, once placed in a position of authority and power, slowly transform into people who seek to wield their influence for their own benefit or the benefit of those who are considered to be their friends. Ideally, "[religious 
authority succeeds by nurturing spiritual growth" (Kretzschmar, 2002:51). This is true. But the antithesis is visible when religious leaders abuse the privilege of wielding power which, in turn, leads to the destruction of many a person's faith. However, genuine Christian leaders would recognize that "... one cannot give up power if one has not yet received or exercised it. Nor can one use power properly if one is not able and willing to relinquish it." (Kretzschmar, 2002:52.) Once power has been tasted, it is very difficult for people to let go of it, often seeing power as a right rather than a privilege or responsibility.

The problem with a traditional understanding of leadership is that it tends to create groups that are either supportive of the leadership or see themselves as failing to benefit from the influence of a particular leader. In social studies this is described as the formation of social identity and the division of people between what are named the "ingroup" and the "out-group" (Ukwuegbu, 2008:531). A current example in politics is found in the leadership tensions within the African National Congress. In an interview with Winnie Madikizela-Mandela, Nelson Mandela's ex-wife and member of the ANC National Executive Committee, she described the leadership structures of the ANC as being fragmented (Forde, 2010:1). Initially, the ANC had a common vision and embraced its vision under a mutually agreedupon leader. Since 2007, the ANC experienced a divided top structure as camps formed around the former president, Mr Thabo Mbeki and the current president, Mr Jacob Zuma (Forde, 2010:1). Within the ANC, during the Mbeki-tenure, the Zuma-group was considered to be the out-group, while those close to Mbeki formed the dominant in-group. Currently, those who once supported or who still show support to the policies put in place by Mr Mbeki and his followers, have assumed the role of the new out-group while Mr Zuma's camp have taken their place as the new in-group.

This tension in the ANC has not only had implications for the leadership, but the followers in turn have had to identify their own social identity. With which group do they identify? Furthermore, there is a decision to be made about their own survival: with which group should they identify in order to guarantee the least amount of risk and the greater possibility for well-being? The notion of social identity therefore requires the individual or group to choose whether to belong to the in-group or the out-group. This has implications for interpersonal relations between the followers, but also between the followers and those in the previous and current leadership (Ukwuegbu, 2008:531; Greenfield \& Marks, 2007:247). 
Religion is not exempt from this dynamic. Rowatt and Tsang (2007: 100) correctly state that although religion seems to be an ideal facilitator of compassion and tolerance in society, it has been found that there is a correlation between an intrinsic sense of religiousness and the practise of implicit and explicit discrimination, especially towards those who do not adhere to the adopted teaching of the church (Rowatt \& Tsang, 2007:115).

South African history shows how different groups of Christians and their leaders formed their own in-groups and out-groups, especially with reference to political orientation and their religious response (De Gruchy, 2004:4-5).

Firstly, the settler churches, whether Afrikaans or English, generally reinforced white political, social and economic hegemony. Within that overall pattern, the Afrikaner churches were supportive of Afrikaner Nationalism and gave legitimacy to apartheid policies; the English-speaking churches were generally more critical though often ambiguously so. (De Gruchy, 2004: 5.)

Further, Christians have divided themselves according to other categories such as those who consider themselves to be liberal, conservative, evangelical, pro-life, pro-choice, gay-friendly, and the list goes on. All of these segments of the Christian faith have their own leaders and those who follow them. The question that needs to be asked is whether this form of leadership and social identity truly makes for a positive difference in their context, besides the benefits derived from advocating their own personal beliefs. A cynical response to this question is admittedly "No" or "Very little".

I would now like to turn to a Christian tradition which had a significant impact on society by forming leaders who transformed their context. I am referring to the Wesleyan tradition of the eighteenth century which, technically speaking, continues in the form of the Methodist movements around the world today.

\section{What makes the Wesleyan movement so special?}

The Wesleyan revival is one of the classic examples of the difference that Christian leadership can make in society. For instance, the early Wesleyan movements were responsible for the establishment of schools for adults, free education for children whose parent's couldn't afford their tuition, and the establishment of Sunday Schools for children who had to work during the week and couldn't attend school. Wesleyans engaged with government and society 
with regard to economic justice (the taxation of the wealthy in order to support the poor), and they challenged the legal system, providing humanitarian aid to prisoners who lived in dreadful conditions, many of whom would be hanged for minor misdemeanours (Gooch, 2006: 79). Their members also contributed to the start of the labour movement. In 1746, the Wesleyans established the first clinic for the poor, who otherwise would not have been able to afford medical treatment, and later played an important role in advocating the equal treatment of slaves. This was the first place where these slaves were admitted to worship and celebrating the Lord's Supper alongside any other person who wished to worship (Gooch, 2006:101).

All of this took place in a relatively short period of time in a country that faced several social issues, including widespread alcohol abuse, poverty and the segregation between the commoners and English aristocracy. It has been suggested, that if it were not for the Wesleyan revival in England, this country may well have followed in France's footsteps by experiencing a bloody revolution (Tyson, 2003:201). Kretzschmar (1998:158) correctly notes that scholars like Thompson (1968:391) dispute the magnitude of the Methodist movement's contribution to the prevention of such a revolution. But it must be said that whether the movement was honest about its mission to the poor or simply placating the social bourgeoisie and proletariat, its influence on change was dynamic and much needed in eighteenth-century England. How did Wesley do this? How did Wesley manage to spark the formation of Christian leaders to such an extent that it altered the course of history in England, and still managed to produce leaders who played significant roles in their communities?

If one were to attribute Wesley's success to the traditional models of leadership, where Wesley was identified as a leader and all others merely served as obedient followers, then one may suggest that Wesley used the church as a platform to advance his own agenda. Instead, he engaged each issue of social justice on the basis of his personal conviction that God values every person and that every person has the ability to become an instrument of God's presence within their particular context.

Critics of Wesley may argue that the man himself is not a good example of leadership as his personality often proved to have some disagreeable aspects. He was a motivated and determined person who was sometimes perceived to come across as being dictatorial and domineering (Tyson, 2003:203). This trait led to the nickname "Pope John" among some of his followers (Tyson, 2003:203). It 
must, however, be noted that although Wesley was strong willed, he showed an approachability to people and was open enough to be called to account for his leadership style at the Methodist Conference of 1766 (Tyson, 2003:203). Here he was answerable to the very people who saw him as their leader. It would be a grave injustice to understand his leadership model and influence through the lens of these personality characteristics (Tyson, 2003:203-205).

\section{Wesley's understanding of leadership}

Maddox (2003:115) draws from John Wesley's sermons in asserting the following: "... the reason that Christian communities around the globe had done so little good in the world was that they were producing so few real Christians". According to Wesley (1831:281; Maddox, 2003:115) there are three reasons for this. The first is that too few churches offered their members an adequate understanding of Christian doctrine. Secondly, where churches provided adequate doctrinal formation, they lacked provision for spiritual discipline. Thirdly, where churches offered doctrinal formation and spiritual discipline, there still seemed to be an absence of the Christian practice of self-denial. In order for Christian leaders to take their place, it is the role of the Christian community to understand the scope of its beliefs, especially as it pertains to the doctrine of salvation. If the Christian community limits its understanding of salvation to merely the forgiveness of sins, then it may very well be assumed that the formation of moral character is an instant event (Maddox, 2003:117) which needs no process. Wesley's order of salvation suggested otherwise, but we will deal with this point later on in this article.

\section{How did Wesley inspire leadership?}

The first point that needs to be made is that for Wesley, leadership began with people (Weems, 1999:17). True leadership is not fixated on a particular ideology or the vision of an individual (Weems, 1999:17). A model of leadership which succumbs to the temptation of ideologies or personal agendas may be effective for a certain period of time, but will not make a significant impact where it is most needed. Wesley saw the needs in his community, and it is clear from his sermon on "Causes of the inefficacy of Christianity" (Wesley, 1831:281-291) that he was tremendously frustrated by the lack of solutions offered by the so-called Christian leaders of his day. Arguably, England's political leaders would have considered themselves to be not only social leaders, but also Christian leaders. The discrepancy between the gospel the leaders believed in and their 
social interaction with those in need was a clear testimony to their ignorance of the Christian message.

True leaders were those who understood their faith to be more than lip-service in the cathedrals. It demanded an awareness of people and their needs. The so-called Christian leaders of the day simply did not inspire change. So, where were these leaders to come from? According to Wesley, true Christian leaders who could make a difference did not necessarily come from those with obvious ability, but simply from the people whom God provided (Weems, 1999:18). Wesley looked for leaders from among the people, not above the people (Weems, 1999:19), because they had a genuine love and awareness of the realities of daily life. The nature of Wesleyan leadership was that it followed the people (Weems, 1999:21), it did not promote an ideology which it sought to convince the people to follow. As Wesley established pockets of worshippers, he instituted the Order of Local Preachers. These were people among the general population who expressed their belief that God had called them to proclaim the Word and to serve the Christian community at large. These were ordinary lay people with very little training, but Wesley recognised and used their passion for the people and God by allowing them to serve as leaders within their local worshipping communities (Weems, 1999:61). It must be noted that in Wesley's day there were not enough ordained clergy to oversee all the parishes in eighteenth-century England. Ministers had to travel between communities, administering the sacraments while they visited. Between these ministerial visits, local preachers took over the leadership role and served their communities. This often entailed more than just fulfilling preaching appointments. Furthermore, these preaching places or societies were not run under the dictatorial finger of a minister, but were managed by the lay people who formed part of these congregations. Later they would be called Society Stewards, and those who took charge of greater Methodist structures, Circuit Stewards. People were given the opportunity of playing a role in the structure, function and mission of the local congregation, so much so that these communities could survive and thrive without the luxury of having a resident minister. So, we need to ask: "What was Wesley's message, and how did this message inspire people to live out their faith in a society-transforming fashion?"

\section{The message that inspired Christian leadership}

Wesley's message is characterised by his use of the term "Christian perfection". At first glance one may dismiss this notion as an idealis- 
tic thought, for no person is perfect and we know that it is impossible for any human being to attain such a state. Wesley understood Christian perfection in a different way. "Perfection is the dynamic goal in which this fullness of love is attained, [where] we become full of God, wholly directed by love." (Lee, 1998:205.) Wesley did not see the expression of Christian life and the dynamics of ordinary life as mutually exclusive terms. To him, God is as real in the streets as in the church. If God's grace and offer of salvation is made for the whole of humankind, then it means that God is not only present and active in the life of the pious aristocrats, but that God is equally concerned with the well-being of the drunkard and his/her family. All people have the potential for Christian perfection, being perfect in the sense that the person, although susceptible to sin, has been redeemed completely and has the capacity to live a righteous life (Wesley, 1993:16-17).

Everybody could, therefore, be a Christian leader, using their particular gifts for the greater benefit of the Christian community. This leadership did not demand a place of authority. This form of leadership asked people to take responsibility for their lives, their homes and their communities. Besides being concerned with their personal holiness, Christians were encouraged to live their faith and so develop social holiness:

Can I be holy if my brother or sister is hungry, or homeless, or in prison, or sick or a slave? Can I be holy if I do not do everything in my power to change the situation in which my brother or sister finds himself or herself? Sometimes what I do is the simple act of charity and personal caring; sometimes what I must do must involve challenging the systems that put my brother or sister in that situation. (Gooch, 2006:44.)

Gooch puts words in Wesley's mouth, but accurately describes the delicate tension Wesley held between personal spirituality (the striving towards Christian perfection) and their Christian social responsibility (social holiness). The Christian, according to Wesley's understanding did not fit into the classic mould of either being a leader or a follower. Each Christian had a duty to take initiative and be a leader in his/her own sphere of influence and responsibility, and to make sure that their Christian witness addressed the situations they encountered.

All their actions had to be centred on bringing glory to God, and not the self (Wesley, 1993:14). "We need a warmed heart and dirty hands" (Gooch, 2006:43), meaning that as much as people dedi- 
cated themselves to the Christian faith, each person also had to engage in social action. Wesley wanted people to turn their lives to God, and this also meant getting involved in action that would influence and change their society (Gooch, 2006:43).

\section{Wesley's strategy for inspiring leaders}

Some contemporaries of Wesley gained converts through their preaching, but none would spark as great a change as the Wesleyan revival. Wesley was a great preacher, but he added something else. He organised people into groups that would support each other, but who would also hold each other accountable in their Christian living and social interaction (Gooch, 2006:9). Church was more than Sunday worship. Besides gathering on a Sunday for worship, fellowship and the celebration of the sacraments, the small groups, called classes, were the instruments that facilitated lasting change in people's lives. It formed a Christian community, which in turn influenced and shaped the rest of society (Gooch, 2006:10). Worshippers were encouraged to participate in these classes under the facilitation of a class leader. A class leader had two functions. Firstly, this person had to make a commitment to see each person in their group at least once a week

... to enquire how their souls prosper, to advise, reprove, comfort or extort, to receive what they were willing to give toward the relief of the preachers, church and poor (Gooch, 2006:28).

Secondly, they were

... to meet with the ministers and the stewards of the society in order to inform the minister of any that are sick, or of any that walk disorderly and will not be reproved and to pay the stewards what they have received (Gooch, 2006:28).

In the classes questions such as the following were asked: "What known sins have you committed since our last meeting?" or "What have you thought, said or done, of which you doubt whether it be sin or not?" (Outler, 1964:180). Wesley believed that accountability would be instrumental in revival (Logan, 1998:124). The use of the term leader in "class leader" is deceptive as it suggests an hierarchical structure to which people had to conform. This was not the case. Class leaders were seen as Christians who were themselves on a spiritual journey, but who facilitated accountability. They themselves also had to be accountable to the group for the way they lived their lives. One can already see that in Wesley's leadership 
model, the only in-group and out-groups that existed were those who lived their lives in accordance with their Christian convictions and those who did not. It was the in-group's mission to witness to the out-group in order for them to find their response in faith, and so lead to the cessation of the out-group. Admittedly this may sound like the quest for the dominance of one group over another, and this would be true if the in-group were promoting its own ideology. The purpose of this in-group, however, pointed beyond itself to Christ. The issue was not which group one belonged to, but inviting those on the outside to become fellow sojourners on the path towards holiness.

These groups provide a context for developing leaders in discipleship, not because the members excel in their Christian living, nor yet because they have a closer relationship with Christ. They serve their congregations as role models in discipleship quite simply because they hold themselves accountable. They monitor their obedience to Jesus Christ in the company of trusted friends. (Watson, 1991b:xv.)

\section{Liberating leadership}

This model of Christian leadership has in modern times even found its way in business. Hindmarsh (1999:83) argues that the modern Methodist Church, particularly in his context in England, can learn from recent management strategies, which have a very similar philosophy as to that offered by the Wesleyan tradition. Hindmarsh (1999:83-84) particularly cites the strategies proposed by Peter F. Drucker, who advocates that leadership is formed when the creative potential of individuals is uncovered and organisations make a concerted effort to set individuals free to express their gifts in ways that not only enhance their own sense of being, but also contribute positively to their environment. Authors like McGregor (1985; cf. also Kessler, 2007:82) postulate that such a leadership style allows people "... the capacity to exercise a relatively high degree of imagination, ingenuity, and creativity in the solution of organizational problems [as these are] ... widely distributed in the population" (McGregor, 1985:47-48).

When practised in the church context, it becomes the fulfilment of what Paul described in 1 Corinthians 12. Each person in the Body has a gift which is neither less nor more important than the gifts of another. The church, according to Paul and Wesley, therefore, should not fall to the temptation of defining leadership purely in terms of authority structures. Leadership is more than that. It in- 
volves the nurturing and formation of each person into becoming a person of influence in his/her own right. Furthermore, the church should avoid a patronising hierarchical structure and trust that the people who grow in faith have the capacity to express their gifts in both a self-affirming way, and in a way that contributes to the church's well-being. The alternative to this model, one based on authoritative and personality centred leadership, often resorts to seductive coercion to gain the commitment and approval of its followers.

Watson (1991a:2) describes this well when he states:

Christian discipleship is presented by and large in our congregations today as an unqualified blessing. People are promised a heightened quality of life, a fulfilment of their gifts and graces, and participation in a supportive and loving community. Moreover they are assured a spiritual relationship with a loving, parental God who is concerned for their personal welfare to a very marked degree. In short, they are offered a very good package of benefits indeed.

When these expectations are not met, it is only natural that followers of this ideology will have feelings of resentment and a general disillusionment with the church and with God. Where leaders are figures who pacify their followers into a mode of obedient following, the cost of an authentic devotion in faith in relation to real life is seldom mentioned. This is particularly characteristic of the so-called "Prosperity Gospel" traditions.

This is where the gift of the Wesleyan model of Christian leadership formation becomes clear. Wesley never allowed those who claimed to belong to the Christian faith to lose sight of their contextual realities. Believers were constantly reminded, both in the preaching of John Wesley and in the context of the classes, to answer the question: "What does it mean to 'take up the cross'?" (Watson, 1991a:3). Christian life, leading to the development of individual and corporate influence, was directed according to the realities of Luke 14:27 (Watson, 1991b:5). The leadership model offered by the Wesleyan tradition created real leaders, sometimes from the most unexpected situations and backgrounds, who would in turn change their world for the better.

All of this was done by taking people and their situations seriously, proclaiming to all that they carried the potential to live out their faith in love (Christian perfection). This was not done in isolation from the world, but demanded that that love be expressed in the world (social 
holiness). Their Christian role was not unleashed in a manner which left people to their own devices, instead they were committed to each other by means of voluntary and disciplined accountability.

Wesley's model of leadership entailed certain values. These can be summarised as humility, awareness of needs, awareness of one's personal responsibility to engage the realities which present themselves and lastly, to be accountable to one's peers. One does not need to be a Christian to adopt such a leadership model. Obviously, to Wesley, all of these values were taught under the banner of the Christian gospel, but to a leader who does not share in the Christian faith, these values will still ensure a leadership dynamic which encourages people to take initiative while still adhering to the accountability structures that may be in place.

Can you imagine your local political leader or social leader taking up their responsibilities under this definition of leadership? What would the world look like if leaders are less concerned with their ability to wield power and more focused on becoming wholesome people (Wesley's Christian perfection). The world could be radically changed if these leaders focus their gift, not on self-enrichment, but on the well-being of others (Wesley's social holiness). Lastly, what would happen if our leaders are accountable, truly accountable in the light of their duties and responsibilities?

\section{Conclusion}

As we enter the 21 st century with its unique problems, we may find that there is less and less room for the practise of traditional forms of leadership where the masses have to follow the whims of the few. It has become apparent that however unproductive it may be, many people prefer to face the real challenges of the modern world expecting "others" to think, act and plan on behalf of the masses. Crime is left to the police to sort out. Economists have to solve the problem of poverty. Politicians have to ensure employment and empowerment. The list goes on. In South Africa, within the recent past, we have witnessed several examples of how people engage in violent protest as they demand the delivery of services and the solving of social problems.

The protesters are correct in calling leaders to be accountable, but it cannot be expected that leaders should solve all social concerns by themselves. It is essential, if this world is to survive challenges such as HIV and AIDS, poverty and climate change, that people depend less on the politics and decisions of the few, but actively take on 
responsibility for their own lives, community and world while still being accountable and functioning within the legal framework of society. Perhaps we would do well as Christians to re-examine the model offered by Wesley. In ministry every person should be encouraged to pursue Christian perfection, to express their faith to those who find themselves in dire situations (social holiness) and to choose to be accountable to fellow sojourners on this path of faith and life.

Adhering to this leadership model makes every person a contributor towards the solution of social needs. It creates the environment for cooperation where every person feels that they are empowered to make a difference according to their own ability, skill and interest. It helps people to look beyond individualistic needs and shapes a future where responsibility and accountability makes every person an instrument of change (for the better).

\section{List of references}

BURNS, J.M. 1982. Leadership. New York: Harper Perennial Modern Classics.

DE GRUCHY, J. 2004. Political landmarks in the response of churches in South Africa, 1936-1994. Journal of theology for Southern Africa, 118:3-26.

FORDE, F. 2010. Unrest would kill Madiba if he knew, she says. The Sunday independent: 1, 24 Jan.

GOOCH, J.O. 2006. John Wesley for the 21st century. Nashville: Upper Room Ministries.

GREENFIELD, E.A. \& MARKS, N.F. 2007. Religious social identity as an explanatory factor for associations between more frequent formal religious participation and psychological well-being. The international journal for the psychology of religion, 17(3):245-259.

GREENLEAF, R.K. 1977. Servant leadership: a journey into the nature of legitimate power and greatness. New York: Paulist.

HINDMARSH, A. 1999. Supports or shackles? Methodist structures in the twenty-first century. (In Craske, J. \& Marsh, C., eds. Methodism and the future: facing the challenge. London: Cassell. p. 73-87.)

KESSLER, V. 2007. On leadership theory: McGregor's theories $X$ and $Y$ in the light of Christian anthropology. Practical theology in South Africa, 22(2):81-99.

KRETZSCHMAR, L. 1998. Privatization of the Christian faith: mission, social ethics and the South African baptists. Ghana: Legon. (Theological Study Series.)

KRETZSCHMAR, L. 2002. Authentic Christian leadership and spiritual formation in Africa. Journal of theology for Southern Africa, 113:41-60.

LEE, H.J. 1998. Experiencing the Spirit in Wesley and Macarius. (In Maddox, R.L., ed. 1998. Rethinking Wesley's theology for contemporary Methodism. Nashville: Kingswood. p. 197-212.) 
LOGAN, J.C. 1998. Offering Christ: Wesleyan evangelism today. (In Maddox, R.L., ed. 1998. Rethinking Wesley's theology for contemporary Methodism. Nashville: Kingswood. p. 113-127.)

MADDOX, R.L. 2003. Formation for Christian leadership: Wesleyan reflections. Summary of proceedings. American Theological Library Association, 57:114-126.

MCGREGOR, D. 1985. The human side of enterprise: 25th anniversary print. New York: McGraw-Hill.

MCGREGOR, D. 2000. The human side of enterprise. (In McGregor, D. Revisited: managing the human side of enterprise. Ed. by G. Heil, W. Bennis \& McGregor, D. New York: Wiley. p.130-144.)

OUTLER, A.C., ed. 1964. John Wesley: a library of protestant thought. New York: Oxford University Press.

ROWATT, W.C. \& TSANG, J. 2007. The relationship between religious orientation, right-wing authoritarianism and implicit sexual prejudice. The international journal for the psychology of religion, 17(2):99-120.

SEKOU, O.U. 2007. Gods: toward a contemporary discourse on religion and democracy. Journal of ecumenical studies, 42(1):98-106.

THOMPSON, E.P. 1968. The making of the English working classes. Harmondsworth: Penguin.

TYSON, J.R. 2003. John Wesley remembered - any more. Churchman, 117(3):201-214.

UKWUEGBU, B.O. 2008. Paraenesis, identity-defining norms, or both? Galatians 5:13-6:10 in the light of social identity theory. The Catholic biblical quarterly, 70(3):524-537.

WATSON, D.L. 1991a. Class leaders: recovering a tradition. Nashville: Discipleship resources.

WATSON, D.L. 1991b. Forming Christian disciples: the role of covenant discipleship and class leaders in the congregation. London: Epworth.

WEEMS, L.H. 1999. Leadership in the Wesleyan spirit. Nashville: Abingdon.

WESLEY, J. 1831. The works of the Rev. John Wesley. Vol. 7. Ed. by T. Jackson. London: Wesleyan Methodist Book Room.

WESLEY, J. 1993. A plain account of Christian perfection. London: Epworth.

\section{Key concepts:}

accountability

holiness

leadership

Wesleyan revival

Kernbegrippe:

heiligheid

leierskap

verantwoording

Wesleyaanse hernuwing 
